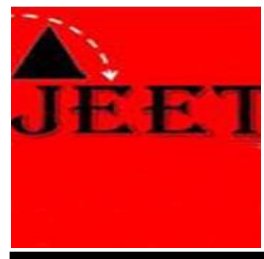

\title{
The Portrait of English Teaching Grounded in Interculturality
}

\author{
Ramsa Aryadi \\ Institut Agama Islam Negeri Curup \\ ramsaamc@gmail.com \\ Jumatul Hidayah \\ Institut Agama Islam Negeri Curup \\ hidayah_jumatul@yahoo.com \\ Sarwo Edy \\ Institut Agama Islam Negeri Curup \\ edywong59@yahoo.com \\ Corresponding Email: ramsaamc@gmail.com
}

\begin{abstract}
The essences of English as a global language, English intercultural communication, and the multiculturality of Indonesians call for the practices of English teaching grounded in interculturality. As the foregoing, this study aimed to describe English teaching based on the perspective of intercultural language teaching (ILT). The ILT perspective was referred to Liddicoat and Scarino's (2013) model. Three English teachers from one of the senior high schools in Kepahiang District were engaged as the participants of this study. This study applied a qualitative method by deploying an instrumental case study design. The data were collected using observation. The data were further analyzed by adopting an interactive model as recommended by Miles, Huberman, and Saldana (2014). Anchored in this model, the obtained data were condensed as well as coded, presented in detail, and properly concluded. The findings of this study revealed that the teachers had applied three principles of ILT, namely active construction, making connections, and
\end{abstract}


interaction. Active construction was represented by some activities such as word quiz, the use of cultures-embedded materials, group work, pair-work communication, and check and recheck with partners. Making connection principle was portrayed from some activities such as directing questions and cultural comparison. Lastly, Interaction principle was depicted from some activities such as the use of cultures-embedded texts, group-interaction, pairwok communication, and check and recheck with partners. It is recommended that further studies be conducted by involving more participants so that richer data with their varieties can be portrayed.

Keywords: English teaching, intercultural language teaching, interculturality

\section{Introduction}

Since the 21st century, English has increasingly been recognized as a global language whose status is as the world's lingua franca (Si, 2018). As a lingua franca, English acts as a language of contact for the world's population (Fang, 2017; Haryani \& Putry, 2020). In such a way, the existence of various cultures affiliated with English users, both native and non-native ones, will be natural (Byram \& Wenger, 2018). Thus, the dimension of English communication becomes intercultural communication (Kramsch, 2013). Related to intercultural communication, the phenomenon of language use in Indonesian society illustrates an intercultural dimension. This is due to the multicultural characteristics of Indonesians originated from different cultures (Idris, 2020). The multiculturality of Indonesians influences the presence of intercultural communication when they are communicating with one another using both Indonesian and English (Hamied, 2012). 
For Indonesian students, ideally English education is systemized based on their multiculturality. Besides, the status of English as the world's lingua franca also shows that English is ideally taught based on the users' multiculturality. In so doing, students will be trained to capably speak English with a variety of speakers from various cultures (Hua, 2013) because Speaking English is so essential to communicate with foreigners (Syafryadin, 2020). The efforts to support multiculturality-based English learning have been made. One of them is through the application of intercultural language teaching (ILT) model as developed by Liddicoat \& Scarino (2013). This teaching model contains five principles, namely active construction, making connections, interaction, reflection, and responsibility.

ILT is a language teaching and learning approach whose design falls into three integral constituents that entail language, culture, and learning (Liddicoat, Papademetre, Scarino, \& Kohler, 2003; Liddicoat \& Scarino, 2013). In the realm of English as a foreign language (EFL) learning, this approach principally conceptualizes that the framework of the English users' culture always determines the way English is used, and English per se represents the users' cultural values. Practically, ILT helps students enhance their understanding of English, their own cultures, and other cultures (Liddicoat \& Scarino, 2013).

Broadly speaking, the application of ILT indicates that English teaching is grounded in interculturality. Since the past five years, many studies have been 
undertaken to address the essence of interculturality in English language teaching and learning. Those studies were oriented towards some foci such as attitudes towards interculturality in English teaching and learning (Tran \& Seepho, 2016; Wang, 2017), the intercultural paradigm of English pedagogy (Morganna, Sumardi, \& Tarjana, 2018a, 2018b; Noviyenty, Morganna, \& Fakhruddin, 2020), Intercultural language curriculum (Porto, 2018), Interculturality as the input of language teachers' reflective practice (Tolosa, Biebricher, East, \& Howard, 2018), and interculturality-related competence (Bal \& Savas, 2020; Idris, 2020).

The above studies have contributed to provide insights as regards interculturality of language pedagogy according to the domains they focused on. However, to the best of the researchers' knowledge, very few studies which have brought the essence of interculturality in the form of an approach of English teaching made use as the umbrella perspective. This condition calls for further studies. There was only one study the researchers could trace that ever applied ILT using Liddicoat, Papademetre, Scarino, \& Kohler's (2003) model as constructed in their first project in 2003. That study was conducted by ALPLP (2005), a sort of an Asian English language project promoting the application of ILT. The forgoing study revealed that ILT as the umbrella perspective of English teaching is promising. There is a gap in terms of time span about 15 years until today wherein ILT-governed model of Liddicoat and Scarino (2013) has not been adopted in a perpetuate way. It is an opportunity of researching for the 
present study to make use of ILT as the umbrella perspective of English teaching.

In addition to the above theoretical gap exhibited by the previous studies, the phenomenon the researchers found in the field (in this regard, one of the senior high schools in Kepahiang, Bengkulu, Indonesia) encouraged the researchers to further observe in detail the practice of English teaching and learning at that school. As revealed from preliminary interviews, English teachers at that school seemed to have a positive attitude towards the issue of interculturality in English teaching. For instance, to represent others, one teacher said:

"It is because if we look at the existing fact, English language plays a role as a primary medium of international communication. It is automatic that English does not merely belong to certain countries, but it has naturally been used by the majority of the world countries". (Interview with teacher 1)

There is a sense of admission from the above interview transcript that the teacher understands the fact that English is an international contact language wherein the users are all people in the world. In an indirect sense, the teacher understands already that world's people are always multicultural, and this leads to the use of English interculturally among them. The above transcript exhibits the teacher's positive cognitive judgment on interculturality. Other teachers at that school seemed to also support this cognition. Such positive cognition represents their positive attitude towards interculturality. 
Based on the status of English as the world's lingua franca; multiculturalism of Indonesian population; the essence of cross-cultural communication for Indonesians; the theoretical gap which calls for studies on ILT-governed model as the perspective on English teaching; and the phenomenon encountered in the preliminary study, the current study is undertaken to describe English teaching implemented at one of the senior high schools in Kepahiang, Bengkulu, Indonesia based on ILT's perspective as proposed by Liddicoat and Scarino (2013). Thus, the following research question is formulated: How is the portrait of English teaching applied by teachers based on the perspective of intercultural language teaching?

\section{Research Methodology}

This study was qualitatively conducted by applying an instrumental case study design. It refers to a study that utilizes a case to understand a particular issue (Stake, 1995). The case in this study was identified by English teaching, and the issue referred to ILT perspective which becomes the reference of English teaching analysis. The rationale beyond the selection of this design was because this study would like to qualitatively probe into the depth alongside the width of the expected data along with presenting appropriate detailed interpretations as well as discussion of the qualitative data. The findings revealed in this study could not be wholly generalized as some numerical data commonly do in a quantitative study. Nonetheless, this study made an effort to 
present the findings which were probably quite generalizable at some point if further studies would like to conform to the detailed procedures or criteria applied in this study.

The participants of this study referred to three English teachers who taught English at a senior high school in Kepahiang, Bengkulu, Indonesia. They aged between 35 and 45 years old. They were selected as the participants by deploying a purposive sampling technique (Fraenkel, Wallen, \& Hyun, 2012). Drawing upon the concept of purposive sampling technique, the participants were selected resting upon some criteria (Ary, Jacobs, Sorensen, Walker, \& Razavieh, 2010). Taking account of this study context, the criteria to select the participants fell into: 1) their study background was English education. 2) They were adequately experienced in English teaching. 3) They were willing to voluntarily join this study as the participants.

The data of this study were solicited from observations assigning field notes as the instrument. Observations were carried out from the $5^{\text {th }}$ to $15^{\text {th }}$ of January 2020. The primary function of observations in this study was to analyze English teaching held by the participants anchored in the perspective of ILT as proposed by Scarino and Liddicoat (2009). During the process of observation, the researchers took field notes to gain every single detail of the expected data. Subsequently, the data were analyzed using Miles, Huberman, and Saldana's (2014) interactive model. Grounded in this model, this study executed four steps consisting of data collection, data condensation, data display, and 
conclusion drawing. As regards data collection, this study relied on observations made while the participants were teaching English in the classrooms. Since the participants already confirmed that they did not want to be recorded in the form of videos, the researchers made a decision to use field notes to take notes of the entire staging of English teaching practices they held. For data condensation, the raw data garnered from observations were condensed by coding them as well as managing them based on valuable themes and subthemes which emerged amid them. Pertinent to data display, they were presented in the form of a table containing some themes coded from the raw data as previously recorded using field notes. The presentation of

data was further followed by detailed explanations representing the actual data got from observations. Such explanations also included data interpretation and discussion. Lastly, the conclusion representing the summary of the overall data was drawn.

\section{Findings and Discussion}

\section{Findings}

The data vis-a-vis English teaching in the perspective of ILT were garnered from observation. The following table 1 and detailed explanations under the table portray the data of the present study. 
Table 1: Teaching and learning activities held by Teachers 1, 2, and 3 coded based upon ILT's principles

\begin{tabular}{|c|c|c|c|}
\hline No & Teachers & ILT's Principle & $\begin{array}{l}\text { The portrait of activities coded } \\
\text { from observational data }\end{array}$ \\
\hline \multirow[t]{6}{*}{1} & \multirow[t]{6}{*}{ Teacher 1} & \multirow[t]{3}{*}{ Active construction principle } & Word quiz \\
\hline & & & $\begin{array}{l}\text { The use of cultures-embedded } \\
\text { material }\end{array}$ \\
\hline & & & Group work \\
\hline & & Making connection principle & Directing questions \\
\hline & & \multirow[t]{2}{*}{ Interacting principle } & $\begin{array}{l}\text { The use of a cultures-embedded } \\
\text { text }\end{array}$ \\
\hline & & & Group interaction \\
\hline \multirow[t]{5}{*}{2} & \multirow[t]{5}{*}{ Teacher 2} & \multirow[t]{2}{*}{ Active construction principle } & Pair-work communication \\
\hline & & & Check and recheck with partners \\
\hline & & Making connection principle & Directing questions \\
\hline & & \multirow[t]{2}{*}{ Interaction principle } & Pair-work communication \\
\hline & & & Check and recheck with partners \\
\hline \multirow[t]{4}{*}{3} & \multirow[t]{4}{*}{ Teacher 3} & Active construction principle & $\begin{array}{l}\text { The use of cultures-embedded } \\
\text { materials }\end{array}$ \\
\hline & & \multirow[t]{2}{*}{ Making connection principle } & Directing questions \\
\hline & & & Cultural comparison \\
\hline & & Interaction principle & Group-work communication \\
\hline
\end{tabular}

\section{English teaching held by teacher 1}

While teaching, Teacher 1 implemented three ILT principles according to the perspective of Liddicoat and Scarino (2013), namely active construction, making connection, and interaction. As observed, active construction principle was depicted from a number of activities assigned by the teacher to students. The first activity was word quiz applied at the beginning of the class. In this activity, students were directed by the teacher to freely communicate with one 
another in order that they could guess some words from the given clues. As such, the meaningfulness of learning activity was to enhance students' capability to interpret indirectness that was realized into giving some clues to guess. Such essence aligned with one of the essential points that existed in active construction principle. The interaction assigned in this activity trained students to capably convey and interpret meanings in ways that they reflected with one another on the shared pragmatics and semantics-embedded utterances which were by nature personal and cultural-based; they carefully thought of relevant ideas to maintain the continuity of their interaction so that it went on coherently during their efforts to guess the clues the teacher gave; they constructed meanings shared by their peers so that they could map and organize ideal responses to those meanings for maintaining fluid interaction during their efforts to guess the clues; and they were also deliberately aware about their communicative positions during interaction so that they could control turn taking to avoid breakdowns of communication. The aforesaid ways represented active construction principle.

The second activity was using a cultures-embedded material in the form of an English descriptive text about Kuta beach as the primary source of the main activity. The text was properly written by an Indonesian writer who was sufficiently competent at English and mastered intercultural English competence. It could be seen from the proper composition of the text that nuanced Balinese culture through an English writing. The text as such was really 
useful since it potentially triggered students to think critically and reflectively while dealing with interculturality. Such potential played a pivotal role to successfully apply the active construction principle.

The third activity was working with groups to deal with a reading text. Once the students read the given text, the teacher led them to discuss together about the text. They were asked to comprehend the content alongside the text organization of the descriptive text. Such discussion process essentially trained them to be engaged in a sort of intercultural communication that was in line with one of the points of the active construction principle. The students would naturally be confronted with a kind of intercultural communication in this activity since they were quite multicultural. When they used English to communicate during the discussion activity, they experienced intercultural communication. The embodied practice as such also powerfully provided students with an opportunity to be aware about cultural diversities faced during English communication. Subsequently, the students were then demanded to present the result of their discussion. This part of activity was brought by one of the members of each group.

In addition, making connection principle was portrayed while the teacher gave students directing questions along with the students' responses in the form of sharing their previous insights as regards Kuta beach. The teacher also helped summarize a wide range of points while students shared their insights. Continuously, the teacher told them some information about Kuta beach in 
that it related to the text which was going to be disseminated. Such an activity fundamentally referred to the application of making connection principle since at this phase the students connected their previous knowledge pertinent to the text topic to the current information shared by the teacher and by the text they were about to read.

Subsequently, interaction principle was depicted in two learning activities. The first was reading a cultures-embedded text. As observed, once the teacher distributed the text about Kuta beach nuancing Balinese culture, the students were demanded to spend some time to read the text comprehensively. Such activity indicated that students interacted with the given text. While reading, they dealt with a text whose content did not nuance their own cultures instead of Balinese cultures. Through this activity, the process of reading the students underwent referred to an interaction taking place in the encounter of two cultures, students' own culture and the culture nuanced in the text. The encounter of those cultures was mediated by English language. This sort of learning activity was meaningful to help students build their intercultural experiences in English use.

The second was group interaction assigned after the students finished reading the given text. In this activity, students were demanded to discuss the contents and the organizations of the given text with their friends in their own groups. The interaction took place within spoken communication realized into a 
discussion activity. Within each group, students dealt with intercultural communication because they shared diverse perspectives during discussion.

\section{English teaching held by Teacher 2}

While teaching, Teacher 2 applied three ILT principles viewed from Liddicoat and Scarino's (2013) model, namely active construction, making connection, and interaction. As observed, there were two activities representing the application of active construction principle. The first was pairwork communication between the activities of brainstorming ideas and writing. This activity was given to students in order to establish a kind of interaction with each other to negotiate their brainstormed ideas. They used English during interaction. In this activity, students were triggered to think critically to check their partners' ideas and to think reflectively to consider the suggested revision. It was in line with the active construction principle where one of the cores was emphasized on developing students' critical and reflective thinking. Basically, critical and reflective thinking was not only done within the negotiation of their brainstormed ideas but also within their interactive encounter with their partners whose cultures were mostly diverse.

The second was check and recheck with partners applied after all students had finished writing their descriptive text describing their chosen historical places. In this stage, the students in their groups switched their works to their friends for getting a recommendation of revision one another. 
Practically, there also took place an interactive communication on account of the discussed subject needed to be critically dealt with. In addition, since most of the students in the classroom came from various cultural communities, the process of communication within such a discussion went on cross-culturally. This activity actually aligned with the active construction principle because it trained students to think critically as well as reflectively during intercultural communication.

Continuously, the implementation of making connection principle was indicated when the teacher asked the students about their experiences of visiting historical places. She posed some directing questions to trigger students to actively share their experiences related to historical places in Indonesia that they had ever visited. Thus, an interactive talk took place. To be discerned, such an activity applied making connection principle because students connected their previous knowledge and experiences to the issues posed by the teacher through her questions.

Furthermore, participant 2 implemented interaction principle through two activities. The first was pair-work communication after the students had brainstormed their ideas to write, and before a writing activity was carried out. The function of free-talk activity was to lead students to help each other by suggesting the proper ideas to write. Grounded in the interaction principle, there were two variants of interactions students dealt with in a free-talk activity. One variant was a written interaction taking place when students read the 
brainstormed ideas their partners had composed. Here, the students interacted with a set of ideas composed based on their partners' perspectives. Their partners' perspectives in this sense would always be affiliated with the essence of culture because one's perspective is categorized as one's culture according to postmodernist view (Kramsch, 2013; Morganna et al., 2018b). When students were interacting with a set of written ideas given by their peers, the students naturally made an effort to build up a third culture which mediated their own perspectives and their peers' written perspectives on what to write into the learned descriptive text. The other variant was a spoken interaction happening when the students with their partners communicated with each other to give suggestions for the sake of a more qualified arrangement of ideas to be written. During such a spoken interaction, students with their partners would negotiate their ideas with each other. Each of their ideas would be diverse. According to non-essentialist paradigm, one's idea is of culture (Morganna, 2017; Morganna et al., 2018b). It was clear that the spoken interaction established between students and their partners demonstrated an encounter between diverse ideas (in this sense, cultures) affiliated with them respectively.

The second was check and recheck with partners done after the students had completely written their descriptive texts. This activity was done in groups. Each student in the group got others to check the composed texts. There were two kinds of interaction taking place during this activity as aligned with the interaction principle. The first interaction occurred when students read and 
comprehended their friends' writing works. An intercultural experience was naturally built up in this activity because the friends' works that the students read were written under the framework of different cultures. Every student underwent such intercultural encounter through reading others' works. The second interaction occurred when the students in their groups gave suggestions for a proper revision of their friends' writing works. Such interaction went on through spoken communication. Since the students were culturally diverse, the interaction that they were engaged in occurred cross-culturally and was mediated by English language. Such interaction naturally helped students build their intercultural experiences, and it was in line with the interaction principle of ILL.

\section{English teaching held by teacher 3}

While teaching, teacher 3 applied three ILT principles in the perspective of Liddicoat and Scarino's (2013) model, namely active construction, making connection, and interaction. Active construction principle was indicated when the teacher used cultures-embedded materials. The teacher used an English native speaker's material in the form of a video telling the procedure to change the ink of a printer cartridge and a non-native English user's material in a kind of a text written by a non-native English user addressing the same topic. Through assigning students to compare both spoken and written procedural text alongside both native English and non-native English variety, active 
construction principle was naturally enacted since the students passed a stage of being engaged in reflective and critical thinking to deal with a cross-cultural encounter set in the given intercultural materials.

In turn, making connection principle was seen in two activities. First, it was when the teacher posed students some directing questions at the beginning of the class. The purpose of this activity was to recall students' memories about the time along with the extent of procedural text they had ever learned in prior. Grounded in making connection principle, such activity was meaningful for students because the students were led to connect the horizon of their related schemata to the procedural text as the given topic on that day. Second, it was when the teacher assigned students an activity of cultural comparison after they watched the given video and read the distributed text. In this activity, the students in their own groups were asked to compare as well as to contrast between the spoken English from its native source and the written one from the non-native source. Such activity evidently applied making connection principle because the students connected the two English varieties depending on the type of its communicative medium alongside the varieties based upon the two existing cultures beyond the use of English. The realm of making connection principle depicted in this activity was a cultural connection.

Subsequently, interaction principle was depicted when the teacher asked students to have group-work communication. This activity was set to students in order to discuss the comparison and contrast between the spoken and written 
procedural texts after they had finished watching the displayed video and reading the given text. In this activity, the students who were mostly culturally different communicated with one another. They used English within the framework of their own cultures, the blueprint of living they brought from their familial and social circles. In addition to this, the materials that they addressed in the discussion were also culturally different since one referred to a spoken procedural text with native English variety, and the other represented a written procedural text with non-native English variety. Interaction principle was naturally applied in this activity. Students were trained to build up their intercultural experiences through a series of interactions with cross-cultural materials and with the interlocutors having diverse cultures during discussion.

\section{Discussion}

Anchored in the observational data, English teaching held by the three teachers was associated with ILT principles in terms of active construction, making connection, and interaction principles. Active construction was represented by some activities such as word quiz as applied by teacher 1, the use of cultures-embedded materials as implemented by teachers 1 and 3 , group work as demonstrated by teacher 1, pair-work communication as exhibited in teaching practice held by teacher 2 , and check and recheck with 
partners as assigned by teacher 2. Making connection principle was portrayed from some activities such as directing questions as posed by the three teachers and cultural comparison as assigned by teacher 3. Subsequently, Interaction principle was depicted from some activities such as the use of culturesembedded text as depicted from teacher l's teaching practice, groupinteraction as portrayed in teachers 1 and 3's teaching practices, pair-wok communication as assigned by teacher 2 , and check and recheck with partners as instructed by teacher 2. However, viewed from ILT principle as proposed by Liddicoat and Scarino (2013), there were two other principles which were not yet applied, namely reflection and responsibility.

As described in Liddicoat's et al. (2003) work, in reflection principle, the students should be encouraged to increase their awareness about knowing, thinking and learning vis-a-vis languages (including their first language and English) and cultures (involving their own and other cultures). This principle also guides students to deeply understand the issues of cultural differences, cultural identities, cultural experiences, interculturality, and otherness (Pennycook, 2017). Those issues always determine and influence the success of cross-cultural English communication. Subsequently, in responsibility principle, teaching and learning should encourage students to be wiser to their own attitude, behavior, and values in using English as a foreign language. When an English interaction is established, the students are guided to be accountable for widening their understanding and acceptance of others' cultures but maintaining their own 
cultural values as well as identities since those components are what they always bring as their own blueprints of living which even start out to arise from their own familial environment (Karatas, Antalya, \& Karatas, 2017; Liu, 2020). In English communication, through this principle, the students are also in charge of their ways of using English across cultures.

Two principles above were not shown from English teaching held by the three teachers. The reasonable factor is because reflection and responsibility principles are challenging and need in-depth pedagogical skills of teaching in a way of interculturality. That is why many studies support that the government should give intercultural teaching training for English teachers. Among those studies are ones conducted by Barrett, Byram, Lázár, Gaillard, and Philippou (2014); Byram and Wenger (2018); Ghasemi, Ahmadian, Yazdani, and Amerian (2020); Liu (2013); Rahim and Daghigh (2019); and Rauschert and Byram, (2017).

\section{Conclusion}

The three teachers engaged as the participants of this study have implemented three ILT principles consisting of active construction, making connection, and interaction. Active construction is represented by some activities such as word quiz, the use of cultures-embedded materials, group work, pair-work communication, and check-recheck activity with partners. Making connection principle is portrayed from some activities such as directing questions and cultural comparison. Interaction principle is depicted from some 
activities such as the use of cultures-embedded text, group-interaction, pairwok communication, and check-recheck activity with partners. However, viewed from ILT model as proposed by Liddicoat and Scarino (2013), there are two other principles which are not yet applied, namely reflection and responsibility. The reasonable factor underlying the absence of these principles is their limited pedagogical skills of intercultural teaching.

\section{References}

ALPLP. (2005). Getting started with intercultural language learning: A resource for schools. Australia: Australian Government Department of Education, Science and Training.

Ary, D., Jacobs, L. C., Sorensen, C. K., Walker, D. A., \& Razavieh, A. (2010). Introduction to research in education. Measurement (8th ed., Vol. 4). USA: Wadsworth, Cengage https://doi.org/10.1017/CBO9781107415324.004

Learning.

Bal, N. G., \& Savas, P. (2020). Intercultural Competence in the Eyes of State School English Language Teachers in Turkey. Journal of Language Education, 6(2), 51-70.

Barrett, M., Byram, M., Lázár, I., Gaillard, M. P., \& Philippou, S. (2014). Developing intercultural competence through education. (J. Huber \& C. Reynolds, Eds.) (Vol. 1). Council of Europe Publishing. F67075 Strasbourg Cedex.

Byram, M., \& Wenger, M. (2018). Making a difference: Language teaching for intercultural and international dialogue. Foreign Language Annals, (December 2017), 1-12. https://doi.org/10.1111/flan.12319 
Candel-Mora, M. Á. (2015). Attitudes towards intercultural communicative competence of English for specific purposes students. Procedia - Social and Behavioral Sciences, 178, 26-31. https://doi.org/10.1016/j.sbspro.2015.03.141

Fang, F. G. (2017). World Englishes or English as a Lingua Franca: Where does English in China stand? English Today, 33(1), 19-24. https://doi.org/10.1017/S0266078415000668

Fraenkel, J. R., Wallen, N. E., \& Hyun, H. H. (2012). How to design and evaluate research in education. 1221 Avenue of the Americas, New York, NY 10020: McGraw-Hill Companies, Inc. https://doi.org/10.1017/CBO9781107415324.004

Ghasemi, A. A., Ahmadian, M., Yazdani, H., \& Amerian, M. (2020). Towards a Model of Intercultural Communicative Competence in Iranian EFL Context: Testing the Role of International Posture, Ideal L2 Self, L2 SelfConfidence, and Metacognitive Strategies. Journal of Intercultural Communication Research, $1-20$. https://doi.org/10.1080/17475759.2019.1705877

Hamied, F. A. (2012). English in Multicultural and Multilingual Indonesian Education. Multilingual Education, 1 (English as an International Language in Asia: Implications for Language Education), 63-78. https://doi.org/10.1007/978-94-007-4578-0_5

Haryani, H., \& Putry, A. (2020). A Collaboration between Communicative Language Teaching (CLT), Audiolingual, and Community Language Learning (CLL) Approach in teaching and learning English at SMA 1 Singorojo Kendal. Journal of English Education and Teaching, 4(1), 127139.

Hua, Z. (2013). Exploring Intercultural Communication. Exploring Intercultural Communication: Language in Action. 
https://doi.org/10.4324/9780203798539

Idris, M. M. (2020). Assessing intercultural competence (IC) of state junior high school English teachers in Yogyakarta. Indonesian Journal of Applied Linguistics, 9(3), 628-636. https://doi.org/10.17509/ijal.v9i3.23213

Karatas, S., Antalya, S., \& Karatas, S. (2017). Teachers' views on multicultural education: sample of Antalya. The Anthropologist, 19(2), 373-380. https://doi.org/10.1080/09720073.2015.11891670

Kramsch, C. (2013). Culture in foreign language teaching. Iranian Journal of Language Teaching Research, 1 (1), 57-78.

Liddicoat, A. J., Papademetre, L., Scarino, A., \& Kohler, M. (2003). Intercultural language learning. Australia: Commonwealth Department of Education, Science and Training.

Liddicoat, A. J., \& Scarino, A. (2013). Intercultural language teaching and learning. West Sussex, UK: Wiley-Blackwell.

Liu, S. (2013). Students ' Attitudes towards Cultural Learning in the English Classroom: A Case Study of Non English Major Students in a Chinese University. International Journal of English Language Education, 1(3). https://doi.org/10.17507/jltr.0802.27

Liu, X. (2020). Comparing multicultural education in China and Finland: from policy to practice. Asian Ethnicity, 1-21. https://doi.org/10.1080/14631369.2020.1760078

Miles, M. B., Huberman, A. M., \& Saldana, J. (2014). Qualitative data analysis: A methods sourcebook. Thousand Oaks, California 91320: SAGE Publications, Inc.

Morganna, R. (2017). Theoretical, pedagogical, practical views, and the shift of genre based instruction. English Franca, 1(1), 81-100. 
https://doi.org/http://dx.doi.org/10.29240/ef.vli1

Morganna, R., Sumardi, S., \& Tarjana, S. S. (2018a). Teaching Culture: The Prevailing Stance of Indonesian EFL Teachers. International Journal of Multicultural and Multireligious Understanding, 5(4), 317-330. https://doi.org/http://dx.doi.org/10.18415/ijmmu.v5i4.169

Morganna, R., Sumardi, \& Tarjana, S. S. (2018b). Immersion vs. construction: The portrayals of culture in Indonesian EFL learning paradigm. Journal of Language and Linguistic Studies, 14(2), 283-304. Retrieved from https://www.jlls.org/index.php/jlls/article/view/969/385

Noviyenty, L., Morganna, R., \& Fakhruddin. (2020). The paradigms of teaching English across cultures: EFL teachers' perspectives. International Journal of Curriculum and Instruction, 12(1), 1-16.

Pennycook, A. (2017). The cultural politics of Englishas an international language. New York: Routledge.

Porto, M. (2018). Does education for intercultural citizenship lead to language learning? Language, Culture and Curriculum, 0(0), 1-18. https://doi.org/10.1080/07908318.2017.1421642

Rahim, H. A., \& Daghigh, A. J. (2019). Locally developed versus global textbooks: an evaluation of cultural content in textbooks used in English language teaching in Malaysia. Asian Englishes, 1-15. https://doi.org/10.1080/13488678.2019.1669301

Rauschert, P., \& Byram, M. (2017). Service learning and intercultural citizenship in foreign-language education. Cambridge Journal of Education, (July), 117. https://doi.org/10.1080/0305764X.2017.1337722

Si, J. (2018). English as a native language, World Englishes and English as a lingua franca-informed materials: acceptance, perceptions and attitudes of Chinese English learners. Asian Englishes, 1-17. 
https://doi.org/10.1080/13488678.2018.1544700

Syafryadin, S. (2020). Students' strategies in learning speaking: Experience of two Indonesian schools. Vision: Journal for Language and Foreign Language Learning, 9(1), 33-46.

Stake, R. E. (1995). The Art of Case Study Research. Thousand Oaks, California: SAGE publications.

Tolosa, C., Biebricher, C., East, M., \& Howard, J. (2018). Intercultural language teaching as a catalyst for teacher inquiry. Teaching and Teacher Education, 70, 227-235. https://doi.org/10.1016/j.tate.2017.11.027

Tran, T. Q., \& Seepho, S. (2016). EFL Learners ' Attitudes toward Intercultural Communicative Language Teaching and their Intercultural Communicative Competence Development. Journal of English Studies, 11.

Wang, J. (2017). Views and Attitudes of intercultural awareness in Chinese teaching and learning in Shanxi Provincial Universities context. Journal of Language Teaching and Research, 8(2), 418-430. 